\title{
State of Eye Protection for Metal Welders in the Workshops of Conakry
}

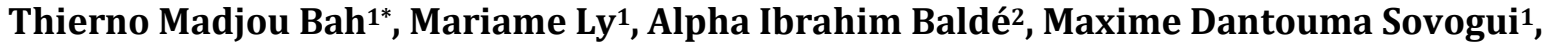 Ramata Balde ${ }^{3}$, Abdoul Karim Baldé1, Alexandre Délamou ${ }^{4}$}

${ }^{1}$ Centre for the Application of the Diploma of Specialized Studies in Ophthalmology, Donka Hospital, Conakry, Guinea

${ }^{2}$ Hospital of the Training of the Armed Forces, Conakry, Guinea

${ }^{3}$ Ophthalmology Service Department, National Hospital of Ignace Deen, Conakry, Guinea

${ }^{4}$ Chair of Public Health, Conakry, Guinea

Email: *madjdesso6@gmail.com

How to cite this paper: Bah, T.M., Ly, M. Baldé, A.I., Sovogui, M.D., Balde, R., Baldé, A.K. and Délamou, A. (2021) State of Eye Protection for Metal Welders in the Workshops of Conakry. Occupational Diseases and Environmental Medicine, 9, 165-172. https://doi.org/10.4236/odem.2021.94012

Received: July 23, 2021

Accepted: September 14, 2021

Published: September 17, 2021

Copyright (C) 2021 by author(s) and Scientific Research Publishing Inc. This work is licensed under the Creative Commons Attribution International License (CC BY 4.0).

http://creativecommons.org/licenses/by/4.0/

\section{Open Access}

\begin{abstract}
Introduction: Welders are an occupational group at high risk for eye injuries. The aim of this study was to investigate the state of eye protection of metal welders in the workshops of Conakry. Material and Methods: The study was cross-sectional, descriptive, and included 180 welders from 45 welding workshops in the city of Conakry for a period of three months. It involved all welding professionals working in an informal unit selected by the study and who had agreed to participate in the study. Results: The average age of the participants was $33.9 \pm 13.4$ years, with extremes of 15 and 68 years. The study found that $99 \%$ of the welders owned glasses, $27 \%$ owned face shields, and $49 \%$ owned welding masks. Goggles were used regularly by $86 \%$ of the welders but were not suitable for welding (98\%). All welders had reported having had an eye injury at least once. Foreign bodies were cited in $81 \%$, arc strike in $65 \%$; eye burns in $61 \%$. However, approximately $81 \%$ of welders did not have first aid kits at their work sites. Conclusion: The use of protective equipment during welding remains very low in the workshops of Conakry, which is the cause of great ocular morbidity among welders.
\end{abstract}

\section{Keywords}

Metal Welder, State of Eye Protection, Conakry

\section{Introduction}

Welders have been identified as a high-risk group for occupational eye injuries due to their continuous exposure to ultraviolet radiation (UV) and welding projectiles [1]. Ocular morbidities, including ocular arc, photokeratosis, diplopia 
and resulting retinal damage are common [2]. The use of protective eyewear during welding helps to reduce the harmful effects of UV visible and infrared radiation. It provides mechanical protection to the eye from welding splatter and reduces visible light to a comfortable level to improve visibility in the welding area. In 2016, an Indian study found that the use of personal protective equipment (PPE) by welders would provide 67\% protection against ocular morbidity [3]. Despite the protection offered by PPE, Nigerian studies conducted in 2011 revealed a low rate of use of eye protection devices not only among welders, but among whole industrial workers. It was observed that only $9.6 \%$ of welders regularly used their protective devices in Calabar [1]. In Guinea, welding is a widely practiced occupation, and most often in an informal manner. Industrial workshops are not easily accessible and vocational training is very limited. In general, these informal welders are unaware of or neglect the risk of eye injuries to which they are exposed during their working life. The objective of this study was to investigate the state of eye protection of metal welders in the workshops of Conakry.

\section{Material and Methods}

The study was a descriptive cross-sectional study including 180 participants from 45 randomly selected informal welding workshops in the five (5) communes of the city of Conakry for a period of three months. Nine workshops in 9 different neighborhoods in each commune were surveyed, with ease of access as the only criterion for selection. In each workshop we interviewed the master, the counter master, two apprentices randomly chosen by the master. The consent of all was obtained. The sampling was non-probability and the sample size was calculated using the minimum sample size formula: $n \geq Z^{2} \times(P \times Q) / i^{2}$; where $P=9.6 \%$ (Nigerian study prevalence [1]), $i=$ required precision estimated at $5 \%, Q=1-$ $P$ (expected phenomenon in the population of welders), $Z=1.96$ (constant depending on the decision threshold at the $5 \%$ risk of error). Using the formula, the minimum sample size was 133 participants, which we increased by $20 \%$ (risk $\beta$ ) to account for completion errors and to maintain the power of the study. A margin of $15 \%$ for refusals was considered, which made a total of $35 \%$; this brought the sample size to 180 participants.

The variables were epidemiological and a direct interview with the respondent enabled the data to be collected. EPI info 7.2 software was used to analyze the data. A frequency distribution was made for the qualitative variables; the mean and standard deviation were calculated for the quantitative variables. References were organized by Zotero software.

\section{Results}

The study included 180 welders from 45 welding sites. The mean age of the participants was $33.9 \pm 13.4$ years and the extremes were 15 and 68 years. The apprentices (41.67\%) were aged between 15 and 30 years, the masters and foremen (34.44\%) between 31 and 45 years. There was a male predominance with a ratio 
of 89 men for 1 woman.

Welders who had not attended school represented $37.22 \%$ compared to $62.78 \%$ of those who had attended school. Of the welders who had attended school, $47.22 \%$ had dropped out of school at the primary level, $13.89 \%$ at the secondary level, and only $1.67 \%$ ( 3 welders) had completed the higher level. The distribution of welders by learning mode is shown in Figure 1.

In the workshops surveyed, $119(66.11 \%)$ used electric arc welding only, 52 (28.88\%) used gas welding only and 9 (5.01\%) used mixed welding.

More than half $(56.11 \%)$ of the welders surveyed had more than 5 years of experience (Table 1 ).

The distribution of welders according to the notion of ocular damage and the periodicity of trauma is shown in the following table (Table 2).

When an eye injury occurred, $75 \%(n=135)$ of the welders surveyed consulted after one hour of the injury, compared to only $25 \%(n=45)$ who visited the ophthalmologist within one hour of the injury. Knowing that traumatic accidents can be frequent in welding, the study also looked at the availability of immediate first aid kits in the workshops. It was found that almost all welders $(80.56 \% ; n=145)$ did not have a kit available, while only $19.44 \%(n=35)$ had kits available in their shops. The availability of protective equipment by the welders surveyed is presented in the table below (Table 3), which reveals that $99 \%$ of welders had welding goggles and two welders had no protective equipment.

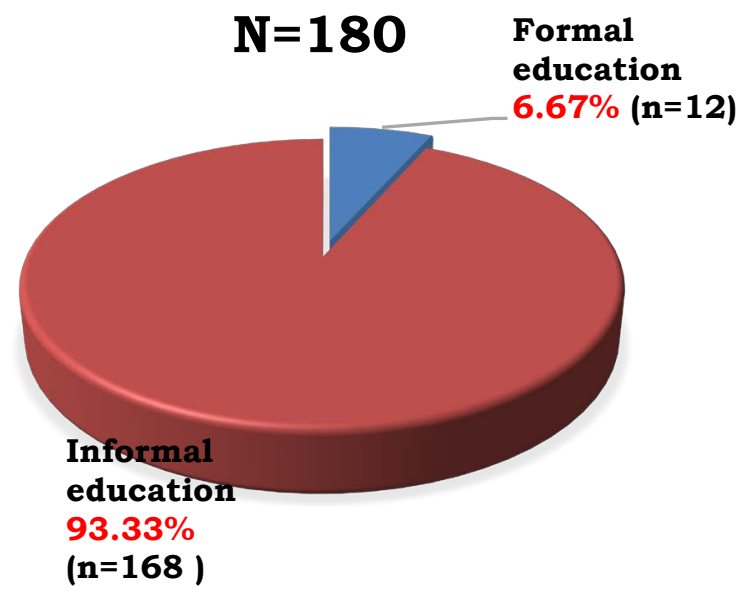

Figure 1. Distribution of welders according to learning mode.

Table 1. Distribution of welders according to the length of their experience.

\begin{tabular}{ccc}
\hline Years of experiences & Effective & Percentage \\
\hline$\leq 1$ & 33 & 18.33 \\
$2-5$ & 46 & 25.56 \\
$\geq 6$ & 101 & 56.11 \\
TOTAL & 180 & 100
\end{tabular}


Table 2. Distribution of welders according to the notion of ocular damage.

\begin{tabular}{cccc}
\hline & $\begin{array}{c}\text { Regularly } \\
n(\%)\end{array}$ & $\begin{array}{c}\text { Occasionally } \\
n(\%)\end{array}$ & $\begin{array}{c}\text { Total } \\
n(\%)\end{array}$ \\
\hline Foreign body & $23(12.78)$ & $123(68.33)$ & $146(81.11)$ \\
Eye burn & $23(12.78)$ & $86(47.78)$ & $109(60.56)$ \\
Bow stroke & $44(24.44)$ & $73(40.56)$ & $117(65.00)$ \\
Wound & $1(0.55)$ & $25(13.89)$ & $26(14.44)$ \\
Contusion & $1(0.55)$ & $41(22.78)$ & $42(23.33)$ \\
\hline
\end{tabular}

$\%$ reported on total of participants, $N=180$.

Table 3. Distribution of welders surveyed according to possession of eye protection equipment.

\begin{tabular}{ccc}
\hline & Effective & $\%$ \\
\hline Protective goggles & 178 & 98.89 \\
Welding masks & 88 & 48.89 \\
Face shields & 49 & 27.22 \\
All equipment available & 25 & 13.89 \\
No equipment available & 2 & 1.11 \\
\hline
\end{tabular}

$\%$ reported on total welders surveyed, $N=180$.

The frequency of use of protective equipment by welders is showed in Table 4.

99.0\% of respondents regular used the protective material and goggles were the most regularly used protective equipment. $13(7.22 \%)$ welders have never used any protective material. Although almost all welders used protective equipment, Figure 2 shows us that $97.75 \%$ were unsuitable for welding.

\section{Discussion}

The aim of occupational health and safety (OHS) is to promote and maintain the physical, mental and social well-being of workers in all occupations [4]. Welding, a skilled occupation practiced since ancient times, is a widely used process today. It consists of permanent joining, in such a way as to ensure the remaining continuity of the material to be joined. It is one of the most intense artificial sources of visible and invisible optical radiation [4] [5]. The purpose of this study was to take stock of the individual and collective protection of welders in the city of Conakry. In metal welding, in Guinea and in other less industrialized parts of the world, electric arc and gas welding are the most commonly used types of welding [6]. Welders assemble and cut metal parts using a flame or electric arc and other heat sources to melt and cut or melt and fuse the metal [4]. The multiplicity of factors, such as heat, burns, radiation (ultraviolet, visible and infrared), noise, gases, electrocution, uncomfortable postures involved in the work, the great variability in the chemical composition of welding fumes, the 
Table 4. Distribution of welders according to the frequency of use of protective equipment.

\begin{tabular}{ccccc}
\hline & Welding masks & Face shields & Protective goggles & Total \\
\cline { 2 - 5 } & $n(\%)$ & $n(\%)$ & $n(\%)$ & $n(\%)$ \\
\hline Regularly & $9(5.00)$ & $15(8.33)$ & $154(85.56)$ & $178(98.89)$ \\
Occasionally & $36(20.00)$ & $70(38.89)$ & $24(8.33)$ & $130(72.22)$ \\
Not once & $6(3.33)$ & $5(2.78)$ & $2(1.11)$ & $13(7.22)$ \\
\hline
\end{tabular}

$\%$ reported on total respondents, $N=180$.

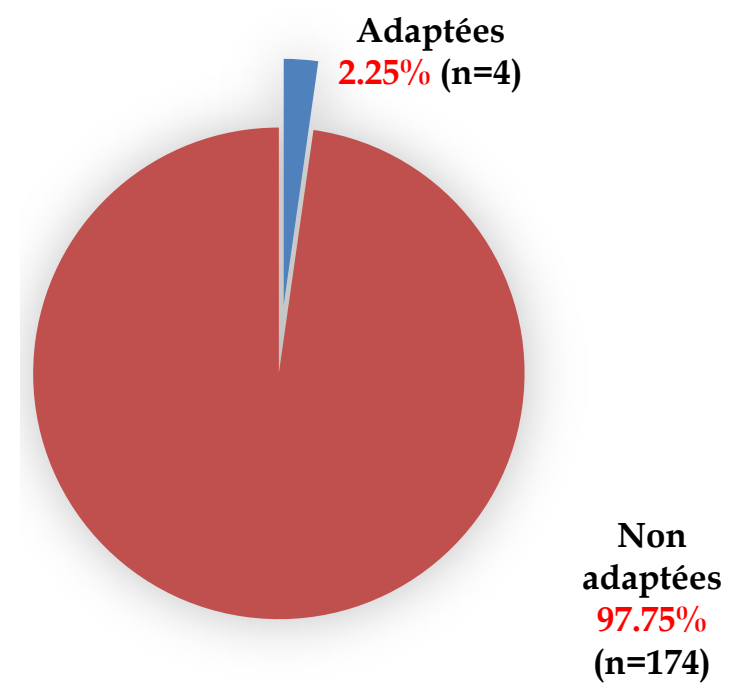

Figure 2. Distribution of glasses according to whether they are suitable for welding or not $(n=178)$.

method used, the surrounding environment and the routes by which these harmful agents enter the body make this occupation a potential health hazard for the welder [1] [4]-[9]. Ocular morbidities, including ocular arc, photokeratitis, double vision and retinal damage related to the welding occupation are common among welders [2] [10] [11]. The limitations of this study were that clinical consultation was not made to determine the sequellar lesions of the ocular involvement. The study had simply focused on interviewing respondents and had taken into account the simple responses of welders. In this series, respondents reported occasional or regular ocular damage such as foreign body, ocular arc, burn, contusion or globe wound. In the series by Syed MH et al. [12] in Lahore, ocular foreign bodies were regularly encountered in $47.1 \%$ of welders and occasionally in 41.4\%; ocular arcing regularly or occasionally in $45.7 \%$. Ajayi IA et al. [6] in Nigeria reported a case of bilateral pigmented maculopathy secondary to electric arc welding in a 48 years old welder. Macular drusen and pterygia were also reported in that series. Studies [1] [4] [5] [6] [7] [8], agree that the lesions encountered in welders, whether occasional or regular, make a statistically significant association with the duration of welding practice. In our case and in the series by Ajayi et al. [1], this was more than five years for the majority of our 
respondents. This link is due to the fact that experienced welders, the majority of whom have no institutional training in our series, have a high self-esteem and neglect all personal protective measures. As welding is an unorganized sector, safety measures are not strictly applied. This was also the finding of Ganesh SK et al. [9] in India. Knowing that traumatic accidents can be common in welding, the study looked at the availability of immediate first aid kits in the workshops. It was found that the majority of the welders did not have a kit available in their workshops. For those who had, the kits available were sometimes incomplete. In Pakistan, Syed MH et al. [12] also found that welders did not have any form of organized occupational health service, first aid training and standardized first aid equipment for medical emergencies. Goggles were the most available protective equipment in our series and the most regularly used equipment in the workshops. Unfortunately, they were mostly not adapted to the welding process. The welders wear simple sunglasses without even the UV mark in almost all cases. This could not protect the eyes against ultraviolet radiation, let alone infrared. The protection was only mechanical, directed against trauma to the eye caused by foreign bodies. Welding masks and face shields were very rarely available and only occasionally used by the vast majority of welders who had them. It was very surprising to find in this study that there were welders who never used any protective equipment during welding. Nigerian studies [1] [13] [14] have also revealed a low level of use of eye protection devices not only among welders, but among whole industrial workers. In this study, the workers who regularly and correctly used the eye protection device had an advanced level of education (high school or university). This indicates the need for institutionalized training in the welding sector. A Thai survey concluded that all welders, at different levels, used protective devices correctly during welding simply because they were sufficiently informed about the health risks of welding [15]. The African States, like this country, should look into the matter and proceed to the reorganization of the whole informal sector in general and welding in particular in order to reduce the harmful effects of welding on the health of the welding population. The lack of training in this section of the population can easily be explained by the delay in schooling in our countries, which varies between 7 and 10 years of age. These young teenagers already see themselves as being sufficiently behind and drop out of school very early on to take up the trades that they believe will provide them with money. The master, needing labour, accepts them very easily in informal apprenticeship. This is justified, in this study, by the very young age of our participants, which varied between 15 and 68 years, with an average age of $33.9 \pm 13.4$ years. Apprentice welders accounted for $41.7 \%$ and were predominantly aged between 15 and 30 years. Ajayi IA et al. [6] in Nigeria found that the age of the respondents ranged from 16 years to 80 years with a mean age of $39 \pm 13$ years. In these studies, it is observed that welding is a male occupation. The proportion of females was very small and represented one female for every 89 males in our case; one female for every 134 males in the Nigerian study [6]. This could be explained by the fact that the wiping of metals 
would require physical strength which is probably the preserve of men.

\section{Conclusion}

Welding is an occupation of the adolescent male, which falls within the informal, unorganized sector. The use of protective equipment during welding remains very low and particularly unsuitable, which is the cause of a great deal of eye morbidity among welders. Efforts should be made at all levels (state and trade unions) to ensure that training and awareness-raising on personal protection are carried out in all welding shops. A more representative study would help to better understand the extent of the phenomenon in the Guinean welding population.

\section{Acknowledgements}

We thank Professors Jeannette TRAORE (Mali) and Oumar Raphiou DIALLO (Guinea) for their unconditional availability to bring quality to this work.

Our recognition and thanks to Doctor Amde-Michael KETEMA for his support and his unceasing accompaniment to the promotion of scientific research in the Republic of Guinea.

\section{Conflicts of Interest}

The authors declare no conflicts of interest regarding the publication of this paper.

\section{References}

[1] Ajayi, I.A., Adeoye, A.O., Bekibele, C.O., Onakpoya, O.H. and Omotoye, O.J. (2011) Awareness and Utilization of Protective Eye Device among Welders in a Southwestern Nigeria Community. Annals of African Medicine, 10, 294-299. https://doi.org/10.4103/1596-3519.87047

[2] Joseph, N., Varun, V., Akash, S.K., Saurish, H., Errol, M, et al. (2017) Nikhilgovind PS. Occupation Hazards-Pattern, Awareness and Preventive Measures among Welders from an Unorganized Sector in India. Journal of Clinical and Diagnostic Research, 11, 23-28. https://doi.org/10.7860/JCDR/2017/24977.9879

[3] Alexander, V., Sindhu, K.N.C., Zechariah, P., Resu, A.V., Nair, S.R., Kattula, D., et al. (2016) Occupational Safety Measures and Morbidity among Welders in Vellore, Southern India. International Journal of Occupational and Environmental Health, 22, 300-306. https://doi.org/10.1080/10773525.2016.1228287

[4] Shyam, S.B., Singh, S.B., Agrawal, R.S., Surya, R.N. and Paras, K.P. (2014) Sensibilisation aux risques professionnels et utilisation des mesures de sécurité chez les soudeurs: une étude transversale de l'est du Népal. BMJ Open, 4, e004646.

[5] Santé au travail. In: Park, K., Ed., Manuel de médecine préventive et sociale, 20 edition, Banarasidas Bhanot Publishers, Jabalpur, Inde, 658-673.

[6] Ajayi, I.A. and Olusola, J.O. (2012) Schéma des maladies oculaires chez les soudeurs dans une communauté nigériane. African Health Sciences, 12, 210-216.

[7] Nitin, J., Varun, V., Akash, S.K., Saurish, H., Errol, M. and Nikhilgovind, P.S. (2017) Risques professionnels-Schéma, sensibilisation et mesures préventives chez les 
soudeurs d'un secteur non organisé en Inde. Journal of Clinical and Diagnostic Research, 11, LC23-LC28.

[8] Bonow, C.A., Marlise, C.V.A., Laurelize, P.R., Vaz, J.C., Valdecir, Z.C. and CezarVaz, M.R. (2013) Littérature scientifique sur les apprentis soudeurs et la médecine préventive: une revue de littérature intégrative. Open Journal of Preventive Medicine, 3, 543-550. https://doi.org/10.4236/ojpm.2013.39073

[9] Ganesh, S.K. and Dharanipriya, A. (2014) Prévalence et schéma des lésions professionnelles sur le lieu de travail chez les soudeurs des régions côtières du sud de l'Inde. Indian J Occup Environ Med, 18, 135-139.

[10] Sakariyau, O.B. and Latip, H.A. (2016) Beyond Financial Performance: A Perspective on Occupational Safety Performance in Automobile SMEs in Nigeria. International Journal of Research Studies in Management, 5, 19-29.

https://doi.org/10.5861/ijrsm.2015.1333

[11] Cezar-Vaz, M.R., Bonow, C.A. and Vaz, J.C. (2015) Risk Communication Concerning Welding Fumes for the Primary Preventive Care of Welding Apprentices in Southern Brazil. International Journal of Environmental Research and Public Health, 12, 986-1002. https://doi.org/10.3390/ijerph120100986

[12] Syed, M.H., Usama, N., Kanwal, A. and Usama, T. (2017) Une évaluation du niveau de sensibilisation et des plaintes signalées concernant les risques pour la santé au travail et l'utilisation d'équipements de protection individuelle chez les soudeurs de Lahore, Pakistan. International Journal of Occupational and Environmental Health, 23, 98-109.

[13] Omolase, C.O. ad Mahmoud, A.O. (2007) Les lunettes de protection des soudeurs: Une évaluation de son appréciation. Nigerian Journal of Surgical Sciences, 17, 54-58.

[14] Davies, K.G., Asanga, U., Nku, C.O. and Osim, E.E. (2007) Effet de l'exposition chronique à la lumière de soudage sur les soudeurs Calabar. Nigerian Journal of Physiological Sciences, 22, 55-58.

[15] Khemjaroon, R., Dangpiam, C. and Chanakok, A. (2006) Utilisation de dispositifs de protection oculaire et problèmes oculaires chez les soudeurs des petites entreprises. Thailand Journal of Health Promotion and Environmental Health, 29, 47-56. 